\title{
Gobak Sodor Games and Cardiovascular Endurance of Elementary School Children
}

\author{
Bayu Insanistyo \\ Pendidikan Jasmani FKIP \\ Universitas Bengkulu \\ Bengkulu \\ bayuinsanistyo@unib.ac.id
}

\author{
Dian Pujianto \\ Pendidikan Jasmani FKIP \\ Universitas Bengkulu \\ Bengkulu \\ dianpujianto@unib.ac.id
}

\begin{abstract}
- the interest of children in game technology as well as the development of technology is increasing more than physical games. Therefore, the level of fitness of a child is low. The aim of the study was to determine the effect of traditional gobak sodor game on cardiovascular endurance of elementary school children. The sample for this study include all elementary school children in grade VI in Seluma District. There was random selection of $\mathbf{2 0}$ children for the purpose of the research. The research design made use of pre-test post-test. The results showed that the game of gobak sodor has significant effect in improving the cardiovascular endurance of elementary school children. From the results of the calculation, it was observed that $t$ observed equals to 8.396, and $t$ critical two tail of 2.045. This shows that $t$ observed is bigger than $t$ critical two tail, so an influence of gobak sodor game is felt on the endurance cardiovascular of children in elementary schools.
\end{abstract}

Keywords-Games, Endurance, Cardiovascular, Children

\section{INTRODUCTION}

The culture of motion in the society started experiencing a shift because of technological developments. This cultural change has a negative impact on physical activities of children. There was free movement for children prior 2000, when they have not been exposed to smart devices like mobile phones, Androids, and tablets. The era after the year 2000 turned out that children tend to have preference for playing games in the form of, android or mobile phones. Children no longer play engage in physical activities such as playing, chasing, playing gobak sodor, and other games that are often done by children in times before now.

This tendency results in a decrease in physical conditions for children. These can be obviously discovered in the armpits of children, the ease with which they experience fatigue and their tendency to be lazy in moving freely. They prefer to stick to their mobile phones or android and relate with the virtual world rather than the physical reality [3]. "Changes in current societies are affecting childhood experiences. Time for outdoor play is diminishing, contributing to more sedentary lifestyles, disconnected from the natural world". Children who do not have childhood are susceptible to mental disorder.

"There is a strong link between mental health and physical health" [10]. This shows that physical activity helps in the promotion of physical and mental healthy conditions. This is because of the fact that children play according to their world.
In addition to strong mental conditions, children who have more playing time with their friends have better cognitive conditions [1].

Based on the above statements, it can be deduced that cultural movement from active movement to lazy movement has significant effect on the physical and mental health as well as the cognitive development of the child. This leads to the review of children activities at this time. In the world today, children are less familiar with traditional games, whereas traditional games actually provide opportunities for their movement both individually and in groups. As it can be seen in the traditional game of gobak sodor.

Gobak Sodor is a game played between two teams. There is a guard squad and there is a team of attackers. The game reflects team work, locomotion, non-locomotion, and manipulative base movement exercises. Apart from these, gobak sodor makes it possible to have the ability of balance, speed, agility, and endurance. Each team consists of 5 players. The attacker tries to get into the guard area. Points are obtained if one attacking player can enter from the front to the back of the line and can return to the front again.

The guard team can also be an attacking team if one of the attacking team can be touched or ambushed by a member of the guard team. The team with the highest points is the winner. The game is not limited by time and it is mostly played when the school is on break or in the afternoon after the children have left their respective schools. The game reflects teamwork and collaborations in winning games, honesty in play, physical abilities of children, and the selection of team play strategies when in either the offensive or defensive position.

As a result of these, the game Gobor Sodor can be a solution to be employed in increasing the the resistance of children to cardiovascular problems. With the use of this game, it is expected that there will be an increment in the number of children who have cardiovascular endurance. 


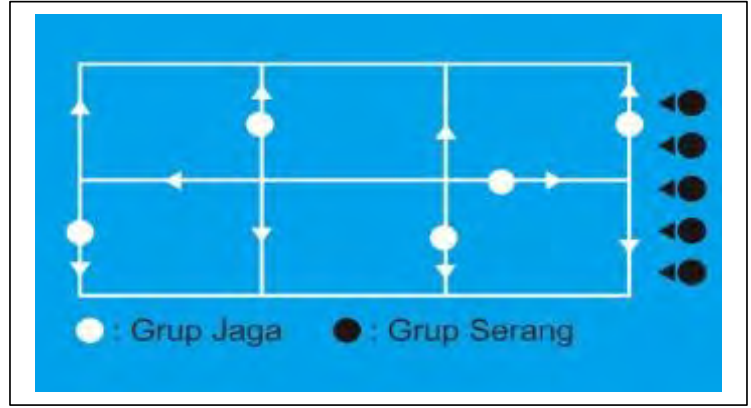

Fig 1. Gobak Sodor Game

\section{METHOD}

This research work employed experimental approach with one group pre-test post-test design. The population of this study with the use of grade 6 primary school students in MIN 7 Seluma, was 30 students. The sampling technique made use of the total sample. Cardiovascular capability data were taken with a $600 \mathrm{~m}$ run from TKJI.

The t-test was used in analyzing the data. The population Sample was made to enter into a training program and meeting for as much as 16 times. The samples practiced for three times in a week. The first week was recorded as the initial test and the last week as the final test.

\section{RESULT}

Before the treatment is given, the initial test data of cardiovascular endurance is as follows:

TABLE I. PRE-TEST DATA

\begin{tabular}{|c|c|c|}
\hline Category & Frequency & \% \\
\hline Excelent & 0 & 0 \\
\hline Good & 1 & 3 \\
\hline Average & 5 & 17 \\
\hline Poor & 12 & 40 \\
\hline Very Poor & 12 & 40 \\
\hline
\end{tabular}

Based on table 1 above, it can be discovered that the student's cardiovascular endurance condition is at a poor and a very poor level. There are 5 children in the average category and just 1 child in the good category. The histogram of pre-test data is presented in the Figure 2 below;

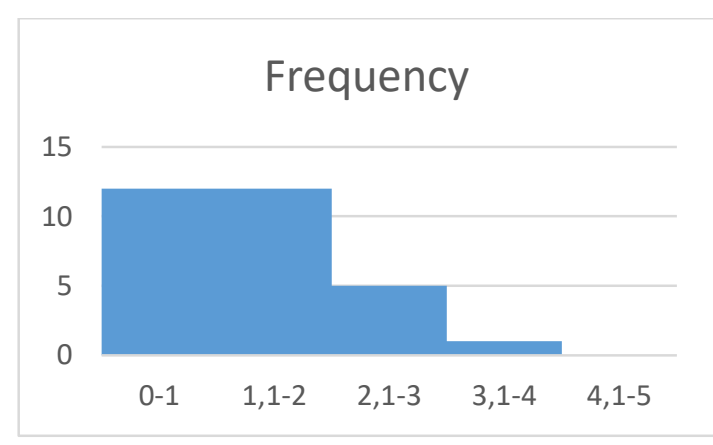

Fig 2. Histogram Pre-Test Data

Based on the above histogram, it was discovered that 24 students were below grade 2 . The values between 2 and 1 are categorized as a poor and a very poor category respectively.
The following are student data after the treatment has been given for 16 times:

TABLE II. POST-TEST DATA

\begin{tabular}{|c|c|c|}
\hline Category & Frequency & \% \\
\hline Excellent & 1 & 3 \\
\hline Good & 6 & 20 \\
\hline Average & 12 & 40 \\
\hline Poor & 10 & 34 \\
\hline Very Poor & 1 & 3 \\
\hline
\end{tabular}

Table 2 above reveals that the students that is in very poor category is just 1 , poor category has 10 students, average category has 12 students, good category has 6 students, and excellent category has 1 student. Here is the histogram of posttest data;

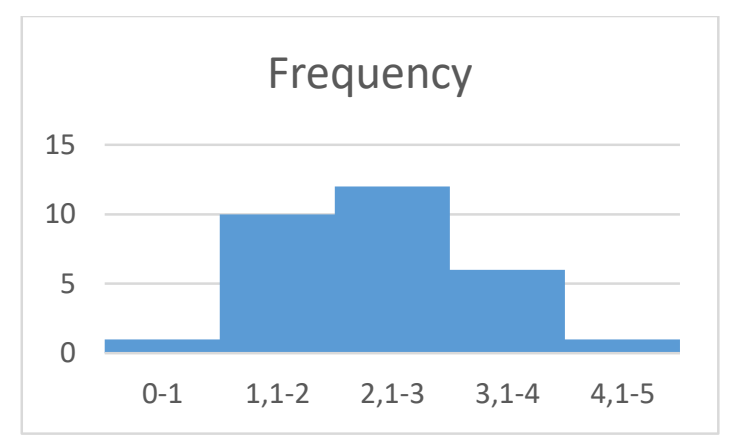

Fig 3. Histogram Post-Test Data

The histogram above shows that there is a clear shift in the cardiovascular endurance ability of students who were on average less than average enough.

\section{A. Statistical Analysis}

Data pre-test and post-test were obtained and tested with the use of t-test. The summary of the t-tests is presented below:

\section{TABLE III. SUMMARY T-TEST}

\begin{tabular}{|l|l|l|}
\hline & Variable 1 & Variable 2 \\
\hline Mean & 3,614 & 2,632666667 \\
\hline Variance & 0,88265931 & 0,256758161 \\
\hline Observations & 30 & 30 \\
\hline Pearson Correlation & 0,766315558 & \\
\hline $\begin{array}{l}\text { Hypothesized Mean } \\
\text { Difference }\end{array}$ & 0 & \\
\hline Df & 29 & \\
\hline t Stat & 8,396381746 & \\
\hline P(T<=t) one-tail & $1,48449 \mathrm{E}-09$ & \\
\hline $\mathrm{t}$ Critical one-tail & 1,699127027 & \\
\hline P(T<=t) two-tail & $2,96897 \mathrm{E}-09$ & \\
\hline t Critical two-tail & 2,045229642 & \\
\hline
\end{tabular}

From the table 3 above, the observational t value is 8.396 . There was comparison of this value with the value of $t$ critical two tail with a degree of freedom 0.05 and a value of 2.045 
was found. Therefore, based on the comparison of $t$ observation with critical $\mathrm{t}$ value, the observation $\mathrm{t}$ value is greater than the critical $t$ value. It can be concluded that traditional gobak sodor game has influence on the cardiovascular endurance of students of MIN 7 Seluma in Bengkulu.

\section{B. Discussion}

Adequate and regular physical activity has a positive impact on the cardiovascular endurance in elementary school students. This statement is founded on the results of the analysis of this study, which has obviously revealed that the programmed traditional game of gobak sodor has the potential of increasing students' cardiovascular endurance at MIN 7 Seluma. Physiologie \& Performance [11] state that children that participate better in physical activities will have a better endurance whenever they are compared with children that engage lazily in physical activities. Children who have good cardiovascular endurance will feel more comfortable in their activities [7]. Children who have good cardiovascular endurance become more confident and have stronger selfconcept [2].

Apart from the fact that there is going to be a better endurance, the child's motor perception will also be better [6]. Motor perception is related to the child's cognitive ability in reading the condition of the surrounding environment. Increased perceptions of child movement will also give children a sense of comfort towards the environment around the school [4]. When the child's endurance is good there is tendency that the child engages in a more longer physical activities which also results in longer understating of the surrounding environment. In addition, there is also going to be increase in the coordination ability of the children. Coordination ability can develop well through programming of physical activity [8].

Cardiovascular endurance is important for children, especially students. Students sit a lot when they are learning and also need to concentrate during the process of learning, good cardiovascular endurance helps in achieving both. Bad cardiovascular endurance makes child sleep and lose concentration easily while studying. Therefore, it is important for parents and teachers to make provision for enough space for physical activity for their children, wards or students as the case may be.

Physical activity for children also provides opportunities for children to socialize with the environment. [9] states that children who have sufficient physical activity with their friends tend to have a good social feeling when compared to children who are alone. Sufficient physical activity helps in attaining a better stay of health [3].

Traditional games gobak sodor is a game that involves physical activity, strategy, and involves many people. When playing gobak sodor children, there is requirement that the children should be in strong physical condition, fast, agile, balanced and have good endurance. Children play in a group, namely groups of attackers and guard groups. As a group of attackers, they organize strategies on how to get as much value and as a group of child watchers trying to get the attackers to fail to earn points. So through this game, there is development of three domains namely cognitive, psychomotor, and affective at the same time. In addition, there will be decrease in the attention of the children to gadgets and this will aid their development and growth in accordance with the necessary stages [5].

\section{CONCLUSION}

From the research that has been carried out, it can be concluded that there is an influence of traditional gobak sodor game on cardiovascular endurance for students of class VI MIN 7 Seluma.

\section{ACKNOWLEDGEMENTS}

We thank Rendra Rivaldi, Ari Sutisyana for the technical assistance they provided as well as the elementary school teachers MIN 7 Seluma for welcoming the authors to their school.

\section{REFERENCES}

[1] O. Abdelkarim, A. Ammar, H. Chtourou, M. Wagner, E. Knisel, A. Hökelmann, \& K. Bös, "Relationship between motor and cognitive learning abilities among primary school-aged children," Alexandria Journal of Medicine, 2017, 53(4), 325-331. https://doi.org/10.1016/j.ajme.2016.12.004

[2] C. Andrade, - K, J. Kramer, M. Garber, \& P. Longmuir, "Changes in self-concept, cardiovascular endurance and muscular strength of children with spina bifida aged 8 to 13 years in response to a 10 -week physical-activity programme: a pilot study," Child: Care, Health and Development, 1991, 17(3), 183-196. https://doi.org/10.1111/j.13652214.1991.tb00689.x

[3] G. Bento, \& G. Dias, development. Porto Biomedical Journal, 2017. 2(5), 157-160. https://doi.org/10.1016/j.pbj.2017.03.003

[4] L. B. Christiansen, P. Lund-cramer, R. Brondeel, S. Smedegaard, A. Holt, \& T. Skovgaard, "Improving children's physical self-perception through a school-based physical activity intervention: The Move for Well-being in School study," Mental Health and Physical Activity, 2018, 14, 31-38. https://doi.org/10.1016/j.mhpa.2017.12.005

[5] David L. Gallahue, J. C. O. Understanding Motor Development infant, Children, Adolescents, Adults (fourth). Singapore: McGrawHill. 1998.

[6] S. Elena, N. Georgeta, G. Cecila, \& E. Lupu, "Perceptual-motor development of children in elementary school," Procedia - Social and Behavioral Sciences, 2014, 114, 632-636. https://doi.org/10.1016/j.sbspro.2013.12.759

[7] I. Kane, R. J. Robertson, C. I. Fertman, E. F. Nagle, W. R. McConnaha, \& Rabin, B. S. "Self-Efficacy and Enjoyment of Middle School Children Performing the Progressive Aerobic Cardiovascular Endurance Run (Pacer)." Perceptual and Motor Skills, 2013, 117(2), 470-483. https://doi.org/10.2466/29.25.PMS.117x23z3

[8] E. Lee, S. C. Development, N. Mar, \& E. L. E. E. Beebe, "Deflection Linked references are available on JSTOR for this article: Motor Learning of Children in Hand and Eye Coordination With Introduction of Prismatic Deflection," controlled aiming test as, 2016 4(1), 6-25.

[9] C. L. Mccoy, \& J. C. Masters, "The Development of Children's Strategies for the Social Control of Emotion Author ( s ),": C. L. McCoy and C. John, Masters Published by: Wiley on behalf of the Society for Research in Child Development Stable URL : http://www.jstor.org/stable/1130, 56(5), 1214-1222. 2016.

[10] J. Ohrnberger, E. Fichera, \& M. Sutton, "Social Science \& Medicine The relationship between physical and mental health : A mediation analysis," Social Science \& Medicine, 2017, 195(October), 42-49. https://doi.org/10.1016/j.socscimed.2017.11.008

[11] L. De Physiologie, \& L. De. Performance, Cardiovascular responses to endurance training in children :, 199-208. 2003 